prolonged use of broad-spectrum antibiotics were identified as risk factors for infection and were observed in all patients with fungal osteomyelitis.

Pseudomonas aeruginosa infection was also observed, which has been described in relation to the length of stay in the hospital, microorganism virulence factors, and invasive procedures. ${ }^{12}$

Treatment duration in this entity has not been clearly defined. In our series, it varied and included prolonged, sequential intravenous-oral administration, depending on the clinical course and the microorganism. In all cases, surgical drainage was performed, which is considered the cornerstone of osteomyelitis management. ${ }^{1,2}$

Functional sequelae are common with this entity. ${ }^{1-7}$ Half of patients in this series developed this type of sequelae. Four suffered the amputation of the affected site.

No other study has assessed mortality in burn patients with osteomyelitis. Among our patients, 1 died due to osteomyelitis-related sepsis.

The limitations of this study include its small sample size, which hinders the possibility of creating a model of risk factors for osteoarticular infection in this type of patients. Also, the study design was not adequate to assess the effectiveness of the implemented treatment strategies.

The main strength of this study was the 10 years of experience in burn children at a tertiary care hospital and the fact that, to our knowledge, it is the largest case series published in this age group.

\section{CONCLUSIONS}

Osteomyelitis was uncommon among pediatric burn patients. Fungal osteomyelitis was the most commonly reported etiology. Fever was the most frequent clinical manifestation. Half of patients had functional sequelae and only 1 patient died.

\section{REFERENCES}

1. Pandit SK, Malla CN, Zarger HV, et al. A study of bone and joint changes secondary to burns. Burns. 1993;19(3):227-8.

2. Barret JP, Desai MH, Herndon DN. Osteomyelitis in burn patients requiring skeletal fixation. Burns. 2000;26(5):487-9.

3. Garcés M, Tapia L, Hoecher F, et al. Clasificación y pronóstico de los quemados. Rev Asist Pública de Santiago. 1971;1:5-9.

4. Patel J, CockerillF, Bradford P, et al.M100-S25. Performance Standards for AntimicrobialSusceptibility Testing; TwentyFifth Informational Supplement. Wayne, PA: Clinical and Laboratory Standards Institute; 2015;35(3):1-16. [Accessed on: June 19 $\left.19^{\text {th }}, 2017\right]$. Available at: https://www.google. com.ar $/$ url? sa $=$ t\&rct $=j \& q=\& e s r c=s \&$ source $=$ web\& $c d=1$ $\&$ cad $=$ rja\&uact $=8 \&$ ved $=0$ ahUKEwi8gbHGkZjVAhXChp AKHZkTAeUQFggnMAA\&url=https $\% 3 \mathrm{~A} \% 2 \mathrm{~F} \% 2 \mathrm{Fwww}$. researchgate.net $\% 2$ Ffile.PostFileLoader.html $\% 3$ Fid $\% 3 \mathrm{D} 58$ 1d9d8fcbd5c2f99c04d4b1\%26assetKey\%3DAS\%253A4249 $85668919296 \% 25401478335887189 \& u s g=A F Q j C N G P T b 4 t h$ WEELSAen57wBDDO-QH5Zg.

5. Canteros C, Davel G, Tiraboschi N, et al. Curso teóricopráctico: El Laboratorio y el Diagnóstico de las Micosis Sistémicas. Buenos Aires: Diagnóstico de Micosis Sistémicas. Departamento Micología. INEI. ANLIS "Carlos G. Malbrán"; 2012. [Accessed on: June 19", 2017 ]. Available at: http:/ / www.anlis.gov.ar/inei/micologia/ wp-content/uploads / 2016/05/guia\%C2\%ADa-Cursoteorico-practico-micosis-sistemicas.pdf.

6. Evans B. Musculoskeletal changes secondary to thermal burns. In Herndon D. Total Burn Care. 4th ed. Philadelphia: Saunders; 2012:551-64.e2.

7. Lollo L, Grabinsky A. Clinical and functional outcomes of acute lower extremity compartment syndrome at a Major Trauma Hospital. Int J Crit Illn Inj Sci. 2016;6(3):133-42.

8. Fodor L, Peled I, Lerner A, et al. Acute osteomyelitis after a minor, 2nd degrees burn of the finger. Burns. 2004; 30(2):185-7.

9. Asamura S, Fukunishi K, Matunaga K, et al. A Baby with Osteomyelitis after a Grade II Burn. Plast Reconstr Surg 2007;120(4):1089-90.

10. Alffie M, Benmeir P, Caspi R, et al. Costal osteomyelitis due to an electrical burn. Burns. 1995;21(2):147-8.

11. Mullins RF, Still JM Jr, Savage J, et al. Osteomyelitis of the spine in a burn patient due to Candida albicans. Bums. 1993;19(2):174-6.

12. Rosanova MT, Stamboulian D, Lede R. Infecciones en los niños quemados: análisis epidemiológico y de los factores de riesgo. Arch Argent Pediatr. 2013;111(4):303-8.

13. Rosanova MT, Basilico $H$, Villasboas M, et al. Infecciones fúngicas enuna unidad de quemados pediátrica. Arch Argent Pediatr. 2011;109(5):437-44.

\title{
Opioid treatment for mixed pain in pediatric patients assisted by the Palliative Care team. Five years of experience
}

\author{
María L. Yazde Puleio, M.D. ${ }^{a}$, Karina V. Gómez, M.D. ${ }^{a}$, Ana Majdalani, M.D. ${ }^{a}$, Vilma Pigliapoco, B.S. ${ }^{a}$ \\ and Gisella Santos Chocler, M.D. ${ }^{a}$
}

a. Hospital General de Niños Pedro de Elizalde, Palliative Care Task Force, Autonomous City of Buenos Aires.

E-mail address:

María L. Yazde Puleio, M.D.: mliliyp@gmail.com
Funding: None.

Conflict of interest: None.

Received: 4-9-2017

Accepted: 8-15-2017 


\section{ABSTRACT}

Pain is defined as an unpleasant sensory and emotional experience associated with actual or potential tissue damage. Depending on its pathophysiological mechanism, it may be classified into nociceptive, neuropathic, and mixed pain. If pain is moderate to severe, a strong opioid should be administered and, when this is the case, morphine is the drug of choice. If morphine is ineffective or causes intolerable adverse effects, opioid rotation is recommended.

Our objective was to describe the drug management for mixed pain used in patients assisted by the Palliative Care team of Hospital General de Niños Pedro de Elizalde between August 2011 and September 2015. A total of 72 patients were included. Their mean age was 10.1 years, and the most common underlying disease was cancer. The initial opioid was morphine in 57 cases; 48 patients received adjuvant drugs. Opioid rotation was indicated in half of cases, and the most common switch was from morphine to methadone.

Key words: morphine, methadone, opioid analgesics, pain, child.

http:/ / dx.doi.org/10.5546/ aap.2018.eng.62

To cite: Yazde Puleio ML, Gómez KV, Majdalani A, et al. Opioid treatment for mixed pain in pediatric patients assisted by the Palliative Care team. Five years of experience. Arch Argent Pediatr 2018;116(1):62-65.

\section{INTRODUCTION}

Pain is defined as an unpleasant sensory and emotional experience associated with actual or potential tissue damage. ${ }^{1,2}$

Two types of pain have been described based on their pathophysiological mechanism: nociceptive and neuropathic. In nociceptive pain, a tissue injury activates nociceptors, and it may be classified into somatic or visceral. ${ }^{3,4}$ Neuropathic pain is caused by structural damage (nerve infiltration by cancer) and/or neuronal dysfunction in the central or peripheral nervous system (inflammatory neuropathy). Sometimes neuropathic pain may coexist with nociceptive pain and cause mixed pain. ${ }^{3}$

An adequate analgesia relieves pain in most children with persistent pain $(80 \%)$, and is based on the following concepts. ${ }^{5}$

- Using a two-phase strategy. With the 2012 modification of the pain ladder developed by the World Health Organization (WHO), non-steroidal anti-inflammatory drugs are recommended for the first phase, followed by strong opioids for the second. Both phases include the use of adjuvant drugs. Morphine is the drug of choice for the second phase of moderate to severe pain treatment.

- Administration at regular intervals.

- Using the corresponding route of administration.

- Individualized treatment.
In the last decades, numerous advances have been made in the study of pediatric pain but drug treatment still requires high quality scientific research that will allow us to move forward in the knowledge of the different drugs used in pediatrics, their therapeutic range, and adverse effects.

Opioid rotation is defined as the clinical practice of switching between different opioids in a set schedule to prevent potential adverse effects or dose escalation. ${ }^{2}$ Methadone may be an alternative to morphine for these patients because of the following:

- Adequate oral absorption.

- Lack of neurotoxic active metabolites.

- Action on opioid receptors and N-methylD-aspartate (NMDA) receptors involved in neuropathic pain.

- Lipophilicity (fast arrival at the central nervous system).

Methadone may improve pain management and reduces the incidence of adverse effects among patients who cannot continue receiving traditional opioids; however, its pediatric use has not been studied in depth. ${ }^{6}$

Our objective was to describe the drug management for moderate to severe mixed pain in patients assisted by the Palliative Care team of Hospital General de Niños Pedro de Elizalde (HGNPE).

\section{MATERIAL AND METHOD}

Design. Descriptive, retrospective study.

Population. All patients with mixed pain (defined by symptom characteristics upon physical examination) assisted by the Palliative Care team of HGNPE in the period between August 2011 and August 2015, and their corresponding medical records, were included.

Patients who did not receive oral medications were excluded because there was no intravenous methadone available in Argentina; incomplete medical records were also excluded.

\section{Study procedure}

For each pain event, the following was recorded:

- Initial opioid treatment: The first opioid indicated once mixed pain was diagnosed as registered in the medical record (morphine, methadone, tramadol).

- Adjuvant treatment: We recorded whether the patient received adjuvant drugs and which ones were indicated (dexamethasone, gabapentin). 
- Opioid rotation: If opioid rotation was indicated once mixed pain treatment was started, we recorded the reason for such indication.

- Presence of adverse effects.

- Lack of treatment response: Patients who required a rapid dose titration without full pain control; it also referred to those who started a weak opioid and switched to a strong opioid.

- Lack of treatment adherence.

- Medical decision: Patients for whom rotation was indicated based on the team's methodological assessment and strategic flexibility at the time of opioid choice, always seeking to individualize treatment for each child in particular, whose clinical situation was changing.?

- Clinical course following rotation: "Adequate" in case of symptomatic relief without a new rotation or adjuvant modification (i.e., no pain and no adverse effects) and "poor" in case of partial symptomatic relief or adjuvant modification (improved pain -a lower score in a numerical or observational scale-, but still with some pain events).

The child's age, underlying disease, and comorbidities, if any, were also recorded.

\section{Statistical analysis}

A descriptive analysis was performed. Value distribution was described as measures of central tendency and dispersion (mean and standard deviation for numerical outcome measures, and percentages and 95\% confidence intervals [CIs] for categorical outcome measures).

\section{Ethical considerations}

The approval of the Research Ethics Committee and the Teaching and Research Committee of the HGNPE was requested and obtained. The study was registered at the Research Registry of the City of Buenos Aires (GCBA) (99/13) under number 461/15.

\section{RESULTS}

A total of 74 patients were identified in the study period; 2 were excluded because they could not receive oral medications given their clinical status. Patients' mean age was $10.09 \pm 5.36$ years; 34 were girls.

In relation to the underlying disease diagnosis, 59 corresponded to cancer; the remaining 13 cases were other diseases (rheumatic and neurological conditions). In addition, 35 of them had no associated comorbidities, 18 had a neurological comorbidity, and only 3 had 2 or more comorbidities.

The initial opioid was morphine in 57 cases, whereas 12 started treatment with other opioids (methadone, tramadol, and codeine).

Forty-eight patients received adjuvant drugs; of them, 20 were given 2 or more drugs.

Opioid rotation was required in 35 patients. The causes for rotation were as follows: in 20 patients, a decision of the medical team; in 6 , lack of treatment response; in 3, adverse effects; in 3 , poor adherence; and in 3 patients, adverse effects and lack of treatment response. The clinical course of patients following rotation was adequate in 32 out of 35 .

\section{DISCUSSION}

Many children with life-threatening diseases experience pain throughout the course of their disease, specifically towards the end of their life. Mixed pain treatment is a particular challenge; the combination of different mechanisms in the origin of pain leads to address each mechanism in an effective manner. Some types of pain are difficult to manage and will require different drug combinations to attain the highest level of pain relief with minimum adverse effects. ${ }^{3,8,9}$

Given that this study focused on moderate to severe mixed pain in children with lifethreatening diseases, opioids were used in all cases; the most common opioid was morphine.

Methadone has pharmacokinetic and pharmacodynamic characteristics that offer advantages for treating the neuropathic component of mixed pain in children. Methadone use has been described in the bibliography for the treatment of nociceptive and neuropathic pain. ${ }^{7,9,10}$ It is a safe opioid for use in children when mixed pain is not controlled by morphine.

Opioid rotation is performed based on individual analgesic response, different pharmacokinetic profiles, and observed crosstolerance. ${ }^{7,11}$

Several studies have been carried out on opioid rotation; its frequency ranges from $11.9 \%$ to $37.5 \%$; the most common causes were uncontrolled pain followed by the presence of intolerable side effects. ${ }^{7}$ In our sample, rotation occurred in approximately half of patients and the most common cause was the medical decision of the treating team. Rotation was decided after a detailed assessment of the case, when analgesia 
was not as desired, and in anticipation of the onset of adverse effects.

The most frequent switch was from morphine to methadone because it had a better pharmacodynamic profile on NMDA receptors.?

This study has a key weakness: the fact that pain is a multidimensional symptom with emotional, spiritual, and social factors that affect children's quality of life and symptom control.

\section{REFERENCES}

1. Goldman A, Hain R, Liben S. Symptom Care. In: Oxford Textbook of Palliative Care for Children. 2nd ed. New York: Oxford University Press; 2012:192-270.

2. Instituto Nacional del Cáncer. El dolor y el cáncer. Versión para profesionales de salud. [Accessed on: June 20 $0^{\text {th }}, 2017$ ]. Available at: https: / / www.cancer.gov/espanol/cancer/ tratamiento/efectos-secundarios/dolor/dolor-pro-pdq.

3. OMS. Directrices de la OMS sobre el tratamiento farmacológico del dolor persistente en niños con enfermedades médicas. 2012. [Accessed on: June 20 ${ }^{\text {th }}$, 2017]. Available at: http:/ / apps.who.int/medicinedocs / documents/s19116es/s19116es.pdf.

4. Astudillo W, Astigarraga I, Salinas A, et al. Manejo de síntomas. In: Medicina Paliativa en Niños y Adolescentes. San Sebastián: Paliativos sin Fronteras; 2015:285-306.

5. McGrath P, Stevens B, Walker S, et al. Pharmacological Interventions. Oxford Textbook of Paediatric Pain. New York: Oxford University Press; 2014.

6. Vara Hernando F, García Ortega E, Garzón Vázquez C, et al. El uso de la metadona en el tratamiento del dolor del enfermo terminal. V Congreso Sociedad Española del Dolor. [Accessed on: August 18 ${ }^{\text {th }}$, 2017]. Available at: http: / / revista.sedolor.es/pdf/2002_11_67.pdf.

7. González-BarboteoJ, Trelis-NavarroJ, Tuca-RodríguezA, et al. Rotación de opioides: una alternativa en el tratamiento del dolor refractario en pacientes con cáncer. Med Clin (Barc) 2010;135(13):617-22

8. Zernikow B, Michel E, Craig F, et al. Use of Opioids for the Management of Pain. Pediatr Drugs 2009;11(2):129-51.

9. Anghelescu D, Faughnan L, Hankins GM, et al. Methadone use in children and young adults at a cancer center: A retrospective study. J Opioid Manag 2011;7(5):353-61.

10. Davies D, DeVlaming D, Hainnes C. Methadone Analgesia for Children With Advanced Cancer. Pediatr Blood Cancer 2008;51(3):393-7.

11. Mercadante S, Ferrera P, Casuccio A, et al. Frequency, Indications, Outcomes, and Predictive Factors of Opioid Switching in an Acute Palliative Care Unit. J Pain Symptom Manage 2009;37(4):632-41.

\title{
Labial adhesions: Experience in a children's hospital
}

\author{
Anahí Rubinstein, M.D. ${ }^{a}$, Gisel Rahman, M.D. ${ }^{a}$, Paula Risso, B.S. ${ }^{b}$ and Dolores Ocampo, M.D. ${ }^{a}$
}

\begin{abstract}
Labial adhesions are defined as the complete or partial fusion of the pudendal cleft due to the agglutination of the labia minora in the midline. They most commonly occur between 3 months and 6 years of life.
\end{abstract}

a. Unit of Pediatric and Adolescent Gynecology, Hospital de Niños "Sor María Ludovica," La Plata, Province of Buenos Aires, Argentina.

b. Scientific Research Commission (Comisión de Investigaciones Científicas, CIC) of the Province of Buenos Aires, Chair of Classical and Bayesian Biostatistics, Degree of Clinical and Industrial Microbiology, School of Veterinary Sciences, Universidad Nacional de La Plata (UNLP), La Plata, Province of Buenos Aires, Argentina.

E-mail addres:

Anahí Rubinstein, M.D.: avrubinstein@yahoo.com.ar

Funding: None.

Conflict of interest: None.

Received: 3-11-2017

Accepted: 8-4-2017
Between January $1^{\text {st }}, 2002$ and December 31 ${ }^{\text {st }}, 2015,425$ girls diagnosed with labial adhesions and seen at the Unit of Pediatric and Adolescent Gynecology of Hospital de Niños de La Plata, Argentina, were analyzed. Their average age was 2.7 years (standard deviation: 2.6years). The most common presentation of labial adhesions was that involving more than $75 \%$ of the total length of the labia $(p<0.0000001)$. A total of $84.2 \%$ of patients showed no symptoms and $4 \%$ had urinary symptoms. Also, $68.4 \%$ of the girls who had a history of urinary tract infection had labial adhesions with a length of involvement of $>75 \%$. Finally, $90.6 \%$ of cases resolved with topical estrogens; and $2.1 \%$ had adverse events.

Key words: labial adhesions, girls, treatment.

http:/ / dx.doi.org/10.5546/ aap.2018.eng.65

To cite: Rubinstein A, Rahman G, Risso P, et al. Labial adhesions: Experience in a children's hospital. Arch Argent Pediatr 2018;116(1):6568.

\section{INTRODUCTION}

Labial adhesions during childhood, also referred to as labial agglutination, are defined as the complete or partial fusion of the pudendal 